〔目的】組成配列の差による画質の変化を，MTF に より調べる。

[方法]被写体組成として, $6 \mathrm{~mm}$ 厚の Al 板, $5 \mathrm{~cm}$ 厚の水, $8 \mathrm{~cm}$ 厚のスチロールファントムで 3 相構成の ファントムをつくり，X線が $\mathrm{Al}$ 一水一スチロールと透 過する場合と，スチロールー水一Al と透過する場合に， 一次線のみがフィルムに到達する幾何学的配置と，一次 線と散乱線が到達する幾何学的配置で，それぞれ矩形波 チャートを求め，乙れを元にして散乱線の MTFを求め た.

[結果]散乱線の MTFは, Al一水一スチロールに比 ベ,スチロールー水一Al の方が高い值を示し, 後者の配 列が MTF が良く，散乱線の画質への悪影響が，より少 ないためであろうと考えられる。

座長集約

国岡 孝志 (鳥取大学)

44は立位ブッキー撮影台について,ブッキー移動によ る振動が画質におよぼす影響について触れた。 カセッテ 保持ワクの振動が画質に影響すると指摘しており，力セ ッデ保持ワクの固定により振動が半減したと述べてい る.との報告が一層高性能の撮影台に改良される足がか りとなるととを期待する。45は胸部写真を対象に物理的 評価亡視覚評価の接点を求めようとした グレーデル法 の応用が好ましく，むっと散乱線を考慮したレスポンス 関数を検討すべきであると指摘した。とのテーマについ て嬞々なる問題点があり，特に高度な読影能力（視覚 評価）を要求される胸部においては両者の一致にはまだ まだ検討を重ねて行く必要があると考え，今後の発展を 期待したし、４6は二元配置法による統計学的処理で画像 評価を行し)，誤差値を含めて検討した評価法として有効 であると述べた：との方法は画像評価の好理のみならず， 放射線管理，種々の実験結果等の判定にも採用されて行 くものと思われる.47は被写体の組成配列の相異による 画質の変化について実験的に検討した。結果はフィルム 側に高密度の被写体を配列した場合が散乱線による画質 への影響が少ないとしている。これは実験的なものであ つて必ずし屯臨床時に適応できるとは言えない問題もあ る.しかし，画質の向上への努力のあり方として評価で きる.

\section{8. 信号検出における立体撮影・拡大撮影の効果}

宇部興産株式会社中央病院

○久米祐司・隅田博臣・瀬畑修二

大野忠正・桜 芫爾

山元大学医学部附属病院：大塚昭義
画像中の微少信号は，その大きさが小さく，加つ蓶音 が多くなるにしたがって検出は困難になる．てのような ノイズ中の微少信号を検出するため，立体撮影や拡大撮 影などの方法が用いられている，われわれは，撮影方法 や，観察方法でどの程度信号検出の能力に差かできるむ のか， ROC 曲線を用いて，評価することを目的とした。

今回は，通常撮影 1 枚観察，通常撮影 2 枚比較観察， 拡大撮影 1 枚観察を行し検詩した結果，(1) 1 枚観察より す 2 枚観察のほうが検出能は高い，(2)拡大撮影すると検 出能は飛踓的に向上する，(3)経験年数の多い観察者のほ うが検出能が高い傾向がうかがえる.などの結果が得ら れた。

\section{ROC 曲線によるじん脑胸部撮影の画像評価（第 2 報）} 積善会附属十全総合病院 ○矢野雅昭・䲨上正志・近藤 保 谷本正恒・奥平智基 愛媛十全医療学院病院：石田光孝 愛媛大学医学部附属病院 川上寿昭

前回アクリル樹脂ビーズを用い記録系の ROC 評価を 報告したが，今回は粉じんにより近い物質を想定し微小 ガラスビーズ $(0.5 \mathrm{~mm} \phi)$ を用いて，カーボンカセッテ とアルミ ECカセッテの比較，およひ増感紙とフィルム の組合せによる画像評価を行った.

ハイスクリーンと RX の組合せの評価が高く,前回の $2 \mathrm{~mm}$ アリル樹脂ビーズの VP と RXL，ハイスクリー ンとRX と逆の現象を示した。 $0.5 \mathrm{~mm}$ ビーズの評価が 低いのは信号が極小な事と，増感紙の粒状性によるすの と考える.じえ肺健康牾断において微小な粉じんを現出 させるには，中間スピードの増感紙にレギュラータイプ のフィルムの組合せによる撮影が良いという結果をえ た。

50. コンピュータ・シミュレーションによるエッジ像の 系列依存性

山口大学病院 ○大塚昭義 愛媛大学病院 吉本政弘

昨年，稲津らは土ッジ像を用いて1次の圥長度を求め， 画質を総合的に評価した。今回，われわれは粒状度，鮮 鋭度，コントラストを変化させたエッシ像について，コ ンピュータ, シュミレーションを行い, 系列依存性を求 めた.乙の值加ら高次 ( 2 次〜 5 次) の觉長度を計算し， 画質評価への適用について検討した。

その結果，粒状度は 2 次の元長度まで相関する。鮮鋭 度については，1次しか相関しない。コントラストは 1 次〜 5 次まで相関する。したがって，コントラストと粒 